\title{
Toxicological Impacts of Gas flaring and Other Petroleum Production Activities in Niger-Delta Environment
}

\author{
${ }^{*}{ }^{1 a} U j o w u n d u$, C. O., ${ }^{1 b}$ Ajoku C.O. ${ }^{10}$ Nwaogu L. A., ${ }^{2 \mathrm{~d} B e l o n w u, ~ D . ~ C ., ~ a n d ~}{ }^{1 \mathrm{e}} \operatorname{Igwe}$ K.O. \\ ${ }^{1}$ Department of Biochemistry, Federal University Technology Owerri, Nigeria. \\ ${ }^{2}$ Department of Biochemistry, University of Portharcourt, Nigeria.
}

${ }^{a} E-m a i l$ address: ujowundu@yahoo.com

${ }^{b}$ E-mail address: clemsabode@yahoo.com

${ }^{\mathrm{C}} \mathrm{E}$-mail address: nwogulinus@yahoo.com

dE-mail address: chukkabell2000@yahoo.co.uk

eE-mail address: kingsloclem@yahoo.com

\begin{abstract}
In this study, the concentrations of inducers of environmental toxicity such as heavy metals and polycyclic aromatic hydrocarbon and biomarkers of environmental toxicants such as oxidative stress enzymes/compounds and liver function enzymes were determined. These parameters were used to assess the pollution status of some Niger-Delta areas; Ebocha/Omoku, Abacheke/Egbema, and Okwuzi/Ohaji, with the aid of two indicator species: cat fish (Ictalurus punctatus) and snakehead fish (Channa argus) from three different water sources; Ebocha/Omoku river, Abacheke river and Okwuzi creek all of which are within the area of oil exploration and production activities in Nigeria. The control fish and water samples were collected from Otamiri River within the Federal University of Technology, Owerri, Nigeria, with no known oil exploration and production activity. The results obtained indicated significant $(p<0.05)$ differences between the exploited and the unexploited environment and the need to incorporate biochemical markers in environmental impact assessment of aquatic environments to complements the classical chemical monitoring.
\end{abstract}

\section{Indexing terms/Keywords}

Petroleum spill; Oil exploitation; Gas flaring; Contamination; Xenobiotics; Oxidative stress markers

\section{Academic Discipline And Sub-Disciplines}

Biochemistry

\section{SUBJECT CLASSIFICATION}

Environmental Biochemistry

\section{TYPE (METHOD/APPROACH)}

Experimental study

\section{Council for Innovative Research}

Journal: Journal of Advances in Chemistry

Vol. 10, No. 2

editorjaconline@gmail.com 


\subsection{INTRODUCTION}

The petroleum industry is organized into four broad sectors; exploration and production of crude oil and natural gas, transport, refining, as well as marketing and distribution [1]. The impact of crude oil exploration and production operations on the environment can be enormous and devastating. Impacts resulting from oil spills, drilling mud and fluid, formation waters and effluent discharge are of great concern because of their deleterious effects [2]. Among the activities of geophysical exploration, the most significant negative effect on the physical and chemical condition of rivers and underground water is the sinking of drill holes and detonation of explosives within the hole [3]. The explosion will disturb natural disposition of aquifers and groundwater chemistry [4].

Petroleum exploration and production companies use wide range of chemicals in their operations, especially for well protection and separation of water from oil. These chemicals pollute the rivers and groundwater systems in the areas where such operations are carried out, if they are not properly controlled according to guidelines and standards set by regulating agencies like the Department of Petroleum Resources (DPR) and the Federal Ministry of Environment [5].

Formation waters and effluent discharges are high in total dissolved solid. Some effluent discharges contain oil sheen and some chemicals injected into wells to inhibit corrosion of equipment or enhance the separation of oil from water. Such water could have detrimental effects on plants and animals [6]. Due to poor monitoring by regulatory authorities these pollutants are discharged directly or indirectly into water bodies without adequate treatment to remove harmful compounds [7]. Water pollution adversely affects plants and animals inhabiting it and also disturbs the natural biological communities. Water pollution is a leading cause of deaths and diseases in thousands of people daily [8]. These contaminants introduce toxins to fish which can lead to diseases, birth defects and death to humans when such fish are consumed [9].

With all these, the aquatic environment has become an easily accessible disposal and sink sites for pollutants. Contamination of water with industrial pollutants can influence biochemical processes of aquatic organisms. This makes it very paramount to utilize an effective monitoring system using biochemical markers for these environmental pollutants. The present study was undertaken to assess and establish the biochemical impact of petroleum production activities on two species of fishes in some selected Nigerians' Niger-Delta environment.

\subsection{MATERIALS AND METHODS}

\subsection{Description of Sampling Area and Sample Collection}

The Niger Delta is an integral part of the sedimentary basins of southern Nigeria and covers an area of about 75000 sqKm. It is the base of crude oil exploration and exploitation in Nigeria. This study was carried out between July and August 2012. Samples were collected from three locations; (i) Ebocha river, which flows through Agip Company in Ebocha Omoku, (ii) from creeks close to Shell Petroleum Development Corporation (SPDC) oil wells and (iii) from creeks of Okwuzi in Ohaji. Crude oil exploration and exploitation are carried out within these water sources. Water samples (1 litre) were randomly collected with sterilized 1.5 litres transparent plastic containers. Water samples were also collected from Otamirri river, which flows across the Federal University of Technology, Owerri (FUTO). The samples were transported to the laboratory for analyses within 24 hours of collection.

\subsection{Fish Sampling and Tissue preparation}

A total of 24 fishes were caught from three sample sites (Ebocha/Omoku river (Eb), Abacheke/Egbema river (Ab) and Okwuzi creek (Ok). It comprises two different species of fishes; Cat fish (Ictalurus punctatus) and five Snakehead fish (Channa argus). In each site three I. punctatus and three $C$. argus were caught by the net method. Their weight varied from $200 \mathrm{~g}$ to $500 \mathrm{~g}$. Fish samples used as control were caught from Otamirri River which flows across FUTO, situated around Ihiagwa, Eziobodo and Obinze villages in owerri, Imo State Nigeria. Petroleum oil exploration and production activities are not carried out in these areas, thus making the location a suitable (uncontaminated) control site [10,11]. The fishes were killed by severing the spinal cord after stunning, blood samples were collected and their livers were excised for biochemical analyses. Samples were immediately stored in ice cooler $\left(-2^{\circ} \mathrm{C}\right)$. This study was conducted in accordance with the national and institutional guidelines for the protection of human subjects and animal welfare [12], and was approved by the Ethics committee of the Department of Biochemistry, Federal University of Technology, Owerri.

\subsection{Determination of Heavy Metals and PAHs in Water Samples}

Heavy metal contents of water samples were determined by the atomic absorption spectrophotometric method as described in standard methods [3]. Polycyclic aromatic hydrocarbons in water were determined with gas chromatography using the USEPA test method for the evaluation of solid waste (sw-846), [13].

\subsection{Assay of Liver Function Enzymes}

Alanine aminotransferase (ALT) and Aspartate aminotransferase (AST) activities in serum were assayed by the method of Reitman et al., [14], alkaline phosphatase activity (ALP) was assayed by the method described by Englahardt, [15].

\subsection{Determination of Oxidative Stress Parameters}

Reduced glutathione (GSH) in the liver samples were determined according to the method of King and Wootton [16]. Glutathione peroxidase (GPX) activity was assayed as described by [17]. Lipid peroxidation product- malondialdehyde (MDA) was estimated as described by [18]. Catalase (CAT) and superoxide dismutase (SOD) activities were assayed according to the methods of [19] and [20] respectively. 


\subsection{Statistical Analysis}

Analysis of variance and other statistical analysis were carried out with the aid of Statistical Package for Social Sciences (SPSS) version 17. Data obtained are presented as Mean \pm Standard Deviation and values of $P<0.05$ was accepted as significant.

\subsection{RESULTS}

The concentration of heavy metals and PAH in Ebocha/Omoku river, Abacheke/Egbema river, and Okwuzi creek (shell) water are shown in Tables 1 and 2. Chromium concentration in the sampled areas was less than the international and national limits, whereas the Nickel concentrations in Ebocha and Abacheke were above these limits. Also, lead concentration in Abacheke was above international and national limits. The concentration $(\mathrm{mg} / \mathrm{kg})$ of the 16 individual PAH compounds are shown.

Table 1: Results of heavy metals and PAHS content of water samples from Ebocha/Omoku river, Abacheke/Egbema river, and Okwuzi creek (shell) water.

\begin{tabular}{lcccc}
\hline Sample identity & PAH (mg/l) & Lead $(\mathrm{mg} / \mathrm{l})$ & $\begin{array}{c}\text { Chromium } \\
(\mathrm{mg} / \mathrm{l})\end{array}$ & Nickel (mg/l) \\
\hline Shell (Okwuzi creek) & 0.0043 & $0.001 \pm 0.00$ & $0.001 \pm 0.00$ & $0.001 \pm 0.00$ \\
Agip (Ebocha river) & 0.0124 & $0.001 \pm 0.00$ & $0.001 \pm 0.00$ & $0.014 \pm 0.001$ \\
Abacheke river & 0.0179 & $0.121 \pm 0.01$ & $0.001 \pm 0.00$ & $0.121 \pm 0.002$ \\
Otamiri (FUTO) & & $0.001 \pm 0.00$ & $0.001 \pm 0.00$ & $0.001 \pm 0.00$ \\
DPR limits (1991) & & 0.05 & 0.03 & - \\
WHO standard (1971) & & $0.01-0.05$ & 0.05 & - \\
FEPA limit (1991) & & 0.05 & 0.05 & 0.01
\end{tabular}

Values shown are mean \pm SD of triplicate determinations. DPR (1991), WHO (1971) and FEPA (1991) limits/standard for potable and Domestic water.

Table 2: Concentrations of PAHs in water samples from, Abacheke/Egbema river, Okwuzi creek (Shell) water and Ebocha/Omoku river.

\begin{tabular}{|c|c|c|c|}
\hline PAHs & $\begin{array}{c}\text { Abacheke } \\
(\mathrm{mg} / \mathrm{kg}) \times 10^{-5}\end{array}$ & $\begin{array}{l}\text { Shell (Okwuzi) water } \\
(\mathrm{mg} / \mathrm{kg}) \times 10^{-5}\end{array}$ & $\begin{array}{c}\text { Agip (Ebocha) water } \\
(\mathrm{mg} / \mathrm{kg}) \times 10^{-5}\end{array}$ \\
\hline Naphthalene & 1.76 & ND & ND \\
\hline Acenaphthylene & 2.66 & 3.85 & 5.86 \\
\hline Acenaphthene & 6.12 & 2.27 & 9.08 \\
\hline Fluorene & 8.47 & 1.04 & 12.4 \\
\hline Phenanthrene & 0.698 & 0.645 & 2.12 \\
\hline Anthracene & 0.176 & ND & ND \\
\hline Fluoranthene & 0.545 & 0.722 & 2.2 \\
\hline Pyrene & 5.52 & 0.979 & 8.98 \\
\hline Benze (a) anthracene & 0.522 & ND & 2.53 \\
\hline Chrysene & 1.95 & 0.348 & 3.12 \\
\hline Benzo (b) fluoranthene & 1670 & 0.42 & 1090 \\
\hline Benzo (k) fluoranthene & 1.95 & 0.302 & 1.78 \\
\hline Benzo (a) pyrene & 0.837 & ND & ND \\
\hline Indeno (1,2,3-cd) pyrene & 90.7 & ND & 102 \\
\hline Dibenz $(a, h)$ anthracene & 0.215 & ND & 0.0367 \\
\hline Benzo $(g, h, i)$ perylene & 0.00905 & ND & ND \\
\hline
\end{tabular}

$N D=$ not $\overline{\text { detected }}$

Table 3, presents the results of oxidative stress enzymes and compounds. The fluctuations in the activities of catalase did not assume a regular trend but the lowest activities were found in C. argus and I. punctatus from Abacheke and Okwuzi 
respectively. Superoxide dismutase activities in $C$. argus from water sources in the polluted environment were significantly lower when compared with the control. However, glutathione peroxidase (GPx) activities were significantly $(P<0.05)$ lower in the fishes harvested from the polluted environment when compared to fishes from unpolluted environment. Except glutathione concentration in C. argus-Control that showed significantly higher concentrations, glutathione concentrations in other samples were none significant. The result showed also, that the concentration of MDA was significantly lower in fishes from unpolluted environment when compared to fishes from polluted area.

Table 4, shows the results obtained from the determination of activities of liver function enzymes; AST, ALT and ALP activities of $C$. argus in polluted areas were significantly $(\mathrm{P}<0.05)$ higher compared to those from the control environment. With $C$. argus from Okwuzi, Ebocha and Abacheke showing the highest AST, ALT and ALP activities respectively. The activities of AST and ALT in I. puntatus from Okwuzi were significantly higher compared to Ebocha, Abacheke and control samples. Similarly, activities of ALP in I. puntatus were the highest. However, AST and ALT activities in I. punctatus from Ebocha and Abacheke were not significantly different $(P<0.05)$ from control samples.

Table 3: Oxidative Stress Enzymes and Compounds

\begin{tabular}{lccccc}
\hline \multicolumn{1}{c}{ Samples } & CAT & SOD & GPX & MDA & GSH \\
\hline C. argus-Ok & $10.07 \pm 0.15^{\mathrm{a}}$ & $1.57 \pm 0.06^{\mathrm{ab}}$ & $262.69 \pm 0.53^{\mathrm{a}}$ & $113.33 \pm 5.77^{\mathrm{a}}$ & $18.66 \pm 1.53^{\mathrm{a}}$ \\
C. argus-Eb & $9.47 \pm 1.37^{\mathrm{ac}}$ & $1.40 \pm 0.10^{\mathrm{a}}$ & $169.44 \pm 0.58^{\mathrm{b}}$ & $103.33 \pm 15.26^{\mathrm{a}}$ & $18.67 \pm 1.53^{\mathrm{a}}$ \\
C. argus-Ab & $7.33 \pm 0.64^{\mathrm{b}}$ & $1.93 \pm 0.21^{\mathrm{b}}$ & $287.77 \pm 0.58^{\mathrm{c}}$ & $260.00 \pm 15.00^{\mathrm{b}}$ & $17.33 \pm 2.08^{\mathrm{a}}$ \\
I. punctatus-Ok & $6.43 \pm 0.50^{\mathrm{b}}$ & $1.70 \pm 0.30^{\mathrm{ab}}$ & $149.41 \pm 0.35^{\mathrm{a}}$ & $316.67 \pm 5.77^{\mathrm{c}}$ & $16.33 \pm 1.53^{\mathrm{a}}$ \\
I. punctatus-Eb & $9.13 \pm 0.21^{\mathrm{ac}}$ & $1.97 \pm 0.23^{\mathrm{bc}}$ & $386.52 \pm 1.15^{\mathrm{e}}$ & $226.67 \pm 11.55^{\mathrm{b}}$ & $16.33 \pm 1.53^{\mathrm{a}}$ \\
l. punctatus-Ab & $8.00 \pm 0.20^{\mathrm{b}}$ & $1.77 \pm 0.42^{\mathrm{bc}}$ & $221.46 \pm 0.41^{\dagger}$ & $280.00 \pm 20.00^{\mathrm{bd}}$ & $16.33 \pm 1.53^{\mathrm{a}}$ \\
I. punctatus-Control & $9.27 \pm 0.15^{\mathrm{ac}}$ & $1.70 \pm 0.20^{\mathrm{ab}}$ & $498.70 \pm 0.58^{\mathrm{g}}$ & $87.33 \pm 6.43^{\mathrm{a}}$ & $19.00 \pm 2.00^{\mathrm{a}}$ \\
C. argus-Control & $8.4 \pm 0.40^{\mathrm{bc}}$ & $2.20 \pm 0.17^{\mathrm{c}}$ & $391.13 \pm 1.01^{\mathrm{h}}$ & $47.00 \pm 2.65^{\mathrm{e}}$ & $26.33 \pm 0.58^{\mathrm{b}}$ \\
F-Value & 12.53 & 3.36 & 89649.73 & 74.87 & 12.98 \\
P-Value & .0001 & .0210 & 0.0001 & 0.001 & .0001 \\
\hline
\end{tabular}

Values shown are mean \pm SD of triplicate determinations. Values in each column with different superscripts are significantly different $(\mathrm{P}<0.05)$. Note; Ok= Okwuzi creek; Eb = Ebocha river; $A B=$ Abacheke river.

Table 4: Activities of Liver Function Enzymes (u/l)

\begin{tabular}{lccc}
\hline Samples & AST & ALT & ALP \\
\hline C. argus-Ok & $30.00 \pm 2.00^{\mathrm{ab}}$ & $26.67 \pm 3.06^{\mathrm{ab}}$ & $48.67 \pm 2.08^{\mathrm{a}}$ \\
C. argus-Eb & $25.33 \pm 3.06^{\mathrm{bc}}$ & $28.00 \pm 2.65^{\mathrm{a}}$ & $54.33 \pm 5.86^{\mathrm{a}}$ \\
C. argus-Ab & $24.00 \pm 2.00 \mathrm{c}$ & $22.67 \pm 3.06^{\mathrm{bc}}$ & $66.00 \pm 7.00^{\mathrm{b}}$ \\
I. punctatus-Ok & $32.002 .00^{\mathrm{a}}$ & $28.67 \pm 1.15^{\mathrm{a}}$ & $50.33 \pm 7.23^{\mathrm{a}}$ \\
I. punctatus-Eb & $14.67 \pm 4.16^{\mathrm{a}}$ & $23.67 \pm 3.21^{\mathrm{bc}}$ & $69.67 \pm 3.21^{\mathrm{b}}$ \\
I. punctatus-Ab & $17.33 \pm 3.06^{\mathrm{d}}$ & $19.33 \pm 1.15^{\mathrm{c}}$ & $45.66 \pm 9.07^{\mathrm{ac}}$ \\
I. punctatus-Control & $14.67 \pm 3.06^{\mathrm{d}}$ & $22.00 \pm 2.00^{\mathrm{c}}$ & $29.00 \pm 1.00^{\mathrm{d}}$ \\
C. argus-Control & $14.00 \pm 2.00^{\mathrm{d}}$ & $21.00 \pm 1.00^{\mathrm{c}}$ & $37.33 \pm 1.15^{\mathrm{dc}}$ \\
F-Value & 20.71 & 6.40 & 18.72 \\
P-Value & 0.001 & 0.001 & 0.001
\end{tabular}

Values shown are mean $\pm S D$ of triplicate determinations. Values in each column with different superscripts are significantly different $(\mathrm{P}<0.05)$. Note; Ok=Okwuzi creek; $E b=$ Ebocha river; $A B=A$ bacheke river. 


\subsection{DISCUSSION}

The toxicological markers of xenobiotic metabolism used to assess the impact of gas flaring, petroleum exploration and exploitation activities in Ohaji/Egbema and Omoku in the Niger Delta have been used in a number of studies which assessed pollution of aquatic environments [21,22,23]. The Niger-Delta aquatic environment since the discovery of crude oil in Nigeria has become a disposal sink for xenobiotics. Water body contamination with industrial pollutants and effluents influences negatively the biochemical processes of aquatic organisms. This brings to bear the use of effective biochemical monitoring system to establish and demonstrate these xenobiotics in the environment.

The results obtained in this study showed that the concentrations of some heavy metals in the water sources were above the tolerable values, indicating heavy metals contamination of rivers and creeks within the gas flare and flow stations. The concentrations of nickel were below the tolerable limit in Okwuzi and Omoku Rivers but above the FEPA limits in Abacheke water samples. The elevated nickel content in Abacheke water could be associated to flared gases and petroleum oil contamination which may adversely affect aquatic organisms [24]. Nickel sulphide fume and dusts are believed to be carcinogenic, and various other nickel compounds may be as well [25]. Nickel carbonyl, $\left(\mathrm{Ni}(\mathrm{CO})_{4}\right)$, is an extremely toxic gas and can explode on exposure to air [26]. The toxicity of the metal carbonyl is a function of both the toxicity of the metal as well as the carbonyl's ability to give off highly toxic carbon monoxide gas [26]. Sensitized individuals may exhibit allergic reactions to nickel, which affects their skin (known as dermatitis).

The concentration of chromium in the water samples were below the permissible limit. This implies that, chromium level poses no toxicological threat at the short term. Long term exposures to high or moderate levels of chromium (VI) can cause damage to the nose (resulting in bleeding, itching, and sores) and the lungs [27]. This assertion imply that, despite the very low level recorded for chromium in the study areas, gradual and continued ingestion may result to its bioaccumulation and finally to biomagnifications in aquatic organisms. Ingesting very large amounts of chromium can cause stomach upsets and ulcers, kidney and liver damage, and even death [28]. A study has shown that, ingestion of large amount of chromium by mice resulted in reproductive problems [25].

The results of this study indicated that lead concentration in water samples from Okwuzi and Omoku were below DPR, WHO and FEPA limits of $0.01-0.05 \mathrm{mg} / \mathrm{l}[1,4,5]$. However, the mean lead concentration of $0.121 \mathrm{mg} / \mathrm{l}$ recorded in Abacheke River indicates contamination of the aquatic environment. Long term ingestion of lead causes a disease called plumbism. Lead ingestion can damage the central nervous system, kidney, liver and the reproductive system [29]. Lead is widely distributed all over the world in the form of its sulphide.

A total of $16 \mathrm{PAHs}$ were detected in the water samples collected from the aquatic environments studied. The highest $\mathrm{PAH}$ concentrations $\left(1.79 \times 10^{-2} \mathrm{mg} / \mathrm{l}\right)$ was recorded at the Abacheke river, followed by $1.24 \times 10^{-2} \mathrm{mg} / \mathrm{l}$ recorded at Agip (Ebocha/Omoku) river and $0.430 \times 10^{-2} \mathrm{mg} / \mathrm{l}$ at the shell (Okwuzi) creek. The most abundant PAH congeners in water samples were benzo (b) fluoranthene (in the three water sources), benzo (1,2,3-cd) pyrene (in Abacheke and Ebocha), and fluorine (also in the three water sources). Benzo (b) fluoranthene and benzo (1,2,3-cd) pyrene are also the most abundant PAH congeners in the bottom sediments as shown in some studies in the Baltic Sea [30] and in Hong Kong [31].

These values correlates positively with fluctuations observed in the oxidative stress and liver function parameters studied in the aquatic animals in these environments. The liver function enzymes in fish samples from the study area showed significantly $(p<0.05)$ higher activities when compared to the control samples. The results showed that the activities of alkaline phosphatase were the highest amongst the three liver function enzymes studied, with peak values in $I$. punctatus from Ebocha water. AST and ALT also showed significantly $(p<0.05)$ higher activities in fishes from the study area when compared to the control samples. These indicate increased hepatocyte damage and leakage of enzymes out of liver cells. The high activities of liver function enzymes in fish samples from the test areas affirm possible exposure to toxic substances. This corroborates the report of high pollution level in water sources in Niger Delta communities [32] Increased environmental pollution makes the bottom sediments a "sink" for toxic hydrophobic chemicals, which can then be released back into the water.

The significantly reduced concentration of glutathione in fishes from rivers and creeks in the petroleum exploration and production areas when compared to $C$. argus from control environment indicates exposure to oxidative stress agents. These agents include xenobiotics such as heavy metals and PAHs which concentrations have been shown to be above the tolerable limits. Low GSH concentration could be attributed to the continuous oxidation of the tripeptide as the system metabolise xenobiotics in the aquatic environment. GSH is also used up metabolically by conjugation to xenobiotics to enhance renal excretion. Oxidants such as $\mathrm{H}_{2} \mathrm{O}_{2}$ formed from the dismutation of superoxide anion radical are transformed into water and oxygen in the presence of catalase and glutathione peroxidase. These metabolic fluctuations affect enzymes activities. This assertion is corroborated by many laboratory and field studies at different rivers involving various fish species $[33,34.35,36]$. Intracellular glutathione protects cells against oxidative stress [37] in a reaction catalyzed by glutathione S-transferase (GST). This conjugative reaction is the principal detoxification pathway for electrophilic xenobiotics which results, usually in a less reactive and more readily soluble product [38]. Similarly, decreased concentration of liver GSH have been observed in English Sole (Pleuronectes vetulus) collected from a PCB- and PAHpolluted section in Washington compared to control sites [39]. The significantly higher concentration of MDA indicates increased lipid peroxidation in fishes from petroleum production environment when compared to fishes from the control area. Studies have shown that exposure to xenobiotics such as heavy metals, carbon tetrachloride $\left(\mathrm{CCl}_{4}\right)$, alcohols lowers SOD and GPx activities and higher values of lipid peroxidation [40,41]. 
The concentrations of pollution markers in the study area confers it a polluted area. This assertion is with respect to the detection of 16 polycyclic aromatic hydrocarbons and some heavy metals in concentrations high enough to cause harm to aquatic organisms [42]. These pollutants emanate from petroleum exploration and production activities in the study area. The flare of gas is the most significant source of pollution [43,11]. The pollution of these areas holds great toxicological implication to humans and other biotic lives. For example; benzo (a) pyrene, benzo (a) anthracene, and dibenz (a,h) anthracene are of great health concern. They are mutagenic and carcinogenic compounds to humans $[44,45]$. Immediate signs and symptoms of acute exposure to PAHs include respiratory tract irritation (if inhaled), gastrointestinal irritation (if ingested), and skin irritation (on dermal exposure). Principal health problems are the formation of DNA and RNA adducts by metabolites of PAHs leading to genetic disorders such as mutation of genes [46].

The concentrations of heavy metals and PAHs obtained correlates positively with the values obtained from the biochemical markers used in this study. For example, the toxicity of water samples which showed significantly high amount of PAHs and heavy metals (especially lead and nickel) was reflected biochemically by the increased activities of liver function enzymes observed in $C$. argus and $I$. punctatus harvested from it when compared to the control samples. The assertion that xenobiotics reduces negatively, the total antioxidant capacity (TAC) of exposed organisms [47] was indicated by the significantly reduced activities of glutathione peroxidase, glutathione, catalase and superoxide dismutase in fishes harvested from petroleum exploration and exploitation environments when compared to samples from the control area.

\subsection{CONCLUSION AND RECOMMENDATION}

This study has shown once more the importance of biochemical markers in assessing and monitoring the environment. It is evident that oil exploration and production activities introduced heavy metals and organic compounds such as PAHs into important water bodies. These pollutants can be traced to the numerous chemicals present in crude oil and some introduced during processing. An environmental friendly remediation process (such as bioremediation) is therefore recommended. This remediation will render the polluted water bodies and environment fit for recreational, domestic and agricultural purposes, because, these areas serve as food basket to Imo and Rivers States.

\section{REFFERENCES}

[1] DPR, 1991. Department of Petroleum Resources Environmental Guidelines and Standards for the Petroleum industry in Nigeria.

[2] Katherine, 1985. Heavy metals in drilling mud waste and their significance upon terrestrial disposal. Acad. Press, N.Y. p. 240

[3] APHA, 1995. Standard methods for the examination of water and wastewater. $19^{\text {th }}$ edition. American public health association, Washington D.C.

[4] WHO, 1971. International Standards for Drinking Water. 3rd ed. Geneva.

[5] FEPA (1991). Federal environmental protection agency guideline and standards for environmental pollution control in Nigeria. Lagos, Nigeria.

[6] Amatya, P.L., Hettiaratchi, J.P.A., Joshi, R.C. 2002. Biotreatment of flare pit waste. J Can Petrol Technol 41 (9): 1-7

[7] Pink, D.H. 2006. Investing in Tomorrow's liquid Gold. Yahoo news. Retrieved 09, 10, 2012.

[8] West, L. 2006. World Water Day: A billion people worldwide lack safe drinking water retrieved 10, 07, 2011

[9] Talwani, M. 2002. The Orinoco heavy oil belt in Venezuela (or heavy oil to rescue?); the James A. Baker III institute for public policy of Rice University Energy study; latin America. September

[10] Ujowundu, C. O., Nwaogu, L. A., Ujowundu, F. N. and Belonwu, D. C. 2013. Effect of Gas Flaring on the Phytochemical and Nutritional Composition of Treculia africana and Vigna subterranean. British Biotechnology Journal 3(3): 293-304.

[11] Ujowundu, C.O., Nwaogu L.A., Igwe, K.O., Ujowundu, F.N., Belonwu, D.C. 2013. Evaluation of the Impact of Oil and Gas Pollutants on the Chemical Composition of Abelmoschus esculentus Moench and Pterocarpus mildbraedii Harms. Journal of Research in Biology 3(3):8611-869, http://jresearchbiology.com/documents/RA0327.pdf.

[12] Van der Oost R., Beyer, J., Vermeulen, N.P.E. 2003. Fish bioaccumulation and biomarkers in environmental risk assessment; a review. Environ Tox Phar 13: 57-149

[13] USEPA 1996. Method 3540C, Soxhlet Extraction. In 'Methods for Evaluation of Solid Waste, Physical/Chemical Methods'. 3rd Edition. USEPA, Office of Solid Waste and Emergency Response: Washington, DC.

.[14] Reitman, S.N. and Frankel S. 1957. A colorimetric method for the determination of serum glutami Oxaloacetic, glutamic pynivic trans-aminess. American Journal of Clinical pathology 28:56-63.

[15] Englehardt, A. 1970. Measurement of alkaline phosphatase. Aerztl Labor 16:42.

[16] King, E.J., Wootton, I.D.P. 1959. Microanalysis in Medical Biochemistry. Page 14. 
[17] Paglia, D.E. and. Valentine W.N. 1967. Studies on the quantitative and qualitative characterization of erythrocyte glutathione peroxidase. J Lab Clin Med 70:158-169.

[18] Wallin, B., Rosengren, B., Shertzer, H.G and Cameyo, G. 1993. Lipoprotein oxidation and measurement of TBARS formation in a single microlitre peate; its use for evaluation of antioxidants. Anal Biochem 208: $10-15$.

[19] Aebi, H.E. 1983. Catalase. In; methods of enzymatic analysis.3 ${ }^{\text {rd }}$ ed. (Bergmeyer, H.U., et al. Ed). Pp. $273-285$. Weinhein. Deerfield Beach, Florida

[20] Xin, Z., Waterman, D.F., Henken, R.M., Harmon, R.J. 1991. Effects of Copper status on neutrophil function, Superoxide dismutase and Copper distribution in Steers. J Diary Sci 74: 3078.

[21] Foster, E.P., Fitzpatrick, M.S., G.W., Schreck, C.B., Yates, J., Spitsbergen J.M., Heidel, J. 2001. Plasma androgen correlation, EROD induction, reduced, condition factor, and the occurrence of organochlorine pollutants in reproductively immature white sturgeon (Acipenser transmontanus) from the Columbia River, USA. Arch Environ Con Tox 41: $182-191$

[22] Siroka, Z., Krijt, J. Randak, T., Svobodova, Z., Peskova, G., Fuksa, J., Hajslova, J., Jarkovsky, J., Janska, M. 2005. Organic pollutant contamination of the river Elbe as assessed by biochemical markers. Acta Vet Brno 74:293-303

[23] Kohler, H.R., Sandu, C., Scheil, V., Nagy-Petrica, E.M., Segner, H. Telcean, I., Stan, G., Triebskorn, R. 2007. Monitoring pollution in river Mures, Romania, part III: biochemical effect markers in fish and integrative reflection. Environ Monit Assess 127: 47 - 54

[24] Brown, E.M. 1997. A conformational study of collagen as Affected by tanniny procedures. Journal of the American Leather chemists Association 92:225-232.

[25] Kasprzak, J., Sunderman, Jr. F.W., Salinikow, K. 2003. Nickel carcinogenesis. Mutation research. 533(1-2): 67- 97 Encyclopaedia of Occupational Health and Safety: chemical, industries and occupations. International Labour Organization. Pp.133 - 139

[26] Stellman, J.M. 1998. Encyclopaedia of Occupational Health and Safety: chemical, industries and occupations. International Labour Organization. Pp.133 - 139.

[27] Cohen, M.D., Kargacin, B., Klein, C.B., Costa, I.N. 1993. Mechanisms of chromium carcinogenicity and toxicity. Critical reviews in Toxicology 23(3): 255-281.

[28] Katz, S.A., Salum, H. 1992. The toxicology of chromium with respect to its chemical speciation: A review. Journal of Applied toxicology 13 (3): 217-224.

[29] Ademoroti, C.M.A. 1996. Environmental chemistry and toxicology. Foludex Press Ltd. Ibadan.

[30] Pikkarainen, A.L. 2004. Polycyclic aromatic hydrocarbons in Baltic Sea sediments. Polycycl Aromat Comp 24: 667679.

[31] Ke, L., Yu, K.S.H., Wong, Y.S., Tam, N.F.Y. 2005. Spatial and vertical distribution of polycyclic aromatic hydrocarbons in mangrove sediments. Sc. Total Environ 340: 177-187.

[32] FEPA, 1999. National Master Plan for Public Awareness on Environment and Natural Resources conservation in Nigeria, FEPA, Garki, Abuja.

[33] Henson, K.L., Stauffer, G., Gallgher, E.P. 2001. Induction of glutathione S-transferase activity and protein expression in brown bullhead (Ameirus nebulosus) liver by ethoxyquin. Toxicol Sci 62:54-60

[34] Perez-Lopez, M., Novoa-Valinas, M.C., Melgar-Riol, M.J. 2002. Glutathione S-transferase cytosolic isoforms as biomarkers of polychlorinated biphenyl experimental contamination in Rainbow trout. Toxicol Lett 136:97-106.

[35] Pandey, S., Parvez, S., Sayeed, I., Haque, R., Bin-Hafeez, B. Raisuddin, S. 2003. Biomarkers of oxidative stress: a comparative study of river Yamuna fish wallago attu (BI. And Schn.). Sci Total Environ 309: 105-115

[36] Ahmad, I., Pacheco, M., Santos, M.A. 2006. Anquilla anquilla. Oxidative stress biomarkers. An in situ study of freshwater wetland ecosystem. Pateira de Fermentelos, Portugal

[37] Mannervik, B. and Danielson, U.H. 1988. Glutathione transferases. Structure and catalytic activity. Crit Rev Biochem 23: 283-337.

[38] Eaton D.L. and Bammler, T.K. 1999.Concise review of glutathione S-transferases and their significance to toxicology. Toxicol Sci 49(2): 156-64.

[39] Nishimoto, M., Leeberhart, B.T., Sanborn, H.R., Krone, C., Varanasi, U., Stein, J.E. 1995. Effects of a complex mixture of chemical contaminants on hepatic glutathione, L-cysteine and gamma-glutamylcystiene synthase in English sole (Pleuronectes vetulus). Environ Toxicol Chem 14: 461-469

[40] Wu, S.J., Lin, Y.H., Chu, C.C., Tsai, Y.H. and Chao, J.C. 2008. Curcumin or saikosaponin improves hepatic antioxidant capacity and protects against CCl4-induced liver injury in rats. J Med Food 11(2):224-9. 
[41] Zheng, X., Long, W., Guo, Y. and Ma, E. 2011. Effects of cadmium exposure on lipid peroxidation and the antioxidant system in fourth-instar larvae of Propsilocerus akamusi (Diptera: Chironomidae) under laboratory conditions. $J$ Econ Entomol 104(3):827-32

[42] Walker, S.E, Dickhut, R.M., Brause, C.C., Sylvia, S., Reddy, C.M. (2005). Molecular and isotopic identification of PAH sources in highly industrialized estuary: Organic Geochemistry 36; 619- 632

[43] Angency for Toxic Substance and Disease Registry (ASTDR). 2009. Toxicity of Polycyclic Aromatic Hydrocarbons (PAHs); case studies in environmental medicine: WB 1519.

[44] USEPA, 1984. Health effects assessment for polycyclic aromatic hydrocarbons (PAHs). Cincinnati, OH: Evenronmental Protection Agency.540/1-86-013

[45] IARC, 1984. Monograph on the evaluation of carcinogenic risk of chemicals to humans. Polynuclear Aromatic Compounds, part 3. Industrial exposures in aluminum production, coal gasification, coke production and iron and steel founding. IARC, Lyon, France.

[46] Sims, R.C. and Overcash, M.R. 1983. Fate of polynuclear aromatic compounds (PNAs) in soil-plant system. Residue Rev 88: 1-68.

[47] Ferrari C.K.B. (2012). Effects of xenobiotics on total antioxidant capacity. Interdiscip Toxicol. 5(3): 117-122. 